\title{
Evaluataion Of Dimension Analysis Through "Mangkang Zoo Tourist Attraction" Promotion Program In Semarang City, Central Java, Indonesia
}

\author{
Tri Yuniningsih \\ Doctoral Program of Public Administration \\ Faculty Of Social And Political Science \\ Diponegoro University \\ Prof. Dr. Sri Suwitri \\ Doctoral Program of Public Administration \\ Faculty Of Social And Political Science \\ Diponegoro University \\ Etty Susilowati \\ Doctoral Program of Public Administration \\ Faculty Of Social And Political Science \\ Diponegoro University \\ Kismartini \\ Doctoral Program of Public Administration \\ Faculty Of Social And Political Science \\ Diponegoro University
}

\begin{abstract}
Mangkang zoo in Semarang city is hopes to become tourist attraction and able to increase tourist amount both of local or foreign because of the strategic location, space between one coral to another is too close, and children playground completely. But there are still weakness such as this zoo management hasn't done maximally and impact to the lack of tourist visitation. This research aims to evaluate implementation promotion development program of Mangkang zoo in Semarang city based on Input dimension, Process, Output and Outcome. Relating to this problem, it is needed societies participation through their role as tourism development object, so that they role will determine successful program of marketing development/ promotion activity. This research uses descriptive qualitative because it explains phenomenon descriptively without determining phenomenon appearing quantity, but the deep information in every phenomenon. This research focuses into evaluation program of Mangkang zoo tourism promotion program in Semarang city. Technique of data collecting is done by Triangulation through deep interview activity with many informants, questionnaire, and documentation. The lack of tourist visiting and tourism stakeholder also the raising local income relating to tourist retribution is one of indication of development program into tourism promotion that is done by Cultural and Tourism Institution in Semarang city hasn't done optimally.
\end{abstract}

Keywords: Income, Interview, Mangkang zoo, Phenomenon and Semarang city. 


\section{INTRODUCTION}

Technical Operational Regional Unit of Margasatwa zoo has a main function in implementing part of technical operational activity of Tourism and Cultural Institution in management field and giving service to this activity. Although the total and wildlife in Semarang zoo hasn't fulfil if it is compared with other zoos, Margasatwa zoo is still interesting and become icon that is able in promoting visitors. The reason is because the strategic location is North Beach known as Pantura land, the space between cage wildlife one to other is too close, and the children playground integrity making this zoo as one of recreation area. Although there are still the lack such as tourist attraction management in Semarang city hasn't managed maximally and impact on the lack of tourist visiting.

The lack of tourist visiting contrary with this zoo strategic location which provides animals and playground area become an interesting phenomenon taken as an object research. So far the promotion activity has been done and managed directly by Cultural and Tourism Institution in Semarang city through a program called as "Marketing Development Program/ Tourism Promotion of Semarang city". These activities is not only consist of expo, trade fair, trade show, event and cultural abstraction, and exhibition or leaflet creating, brochure or guiding book and tourism map but also through exhibitions that is done both of local, national and international. But the aiming program of tourism promotion hasn't reached maximally and tending to decreasing fact (Elyance Suci, 2012:13).

Every region tries promoting their regional aiming to increase tourist visitation. To reach this goal, the Central Java Province Government has proclaimed Visit Central Java program since 2013. This program is become as effort in increasing society prosperity through tourism activity. To reach the success program need to be followed with preparation from all regions in Central Java Province. This preparation can be started by advantaging and expanding natural resource potency existence in Central Java.

Semarang city has much tourism potential than able to be become as business sector. The tourism potential basis on the natural resource based on the tourism promotion program especially for Semarang city zoo refer to the marketing development program/ tourism promotion by Cultural and Tourism institution. It aims to creating Semarang city image both of in Indonesia and International as an effort in increasing gratitude of local cultural industry and national. Relating to this act, it is needed participation or society role through taking a role as tourism development role so that they are very decide this successful program of these marketing development or tourism promotion. But there is still problem in implementing this act such as many societies haven't understood about Sapta Pesona as tourism development supporting. Whereas it takes a role as tourist mindset or visitor that classified into security condition, cleaning, arranged, fresh, beautiful, friendly, and memorizing so that it will create ownership senses of this destination.

The lack of supporting program into promotion development or tourism marketing can be seen from flood condition because of human factors. It can impact to Semarang city image that is more known as flooding city than this tourism potential. Based on this indication above, it can be assumed that tourism promotion program hasn't done maximally. While they are very supporting tourism development, because it will increase currency exchange source, extending job vacancy and business, stimulating regional development, and introducing nature and local culture.

The marketing or promotion activity that has been done by Semarang city surely managed by Cultural and Tourism institution proclaimed into a program called as tourism marketing 
development program. This activity is as follow as exhibition, expo or exposition, industrial show, trade fair, trade. This exhibition that is done by relating institution is not only local or national expo but also internationally. Many events and culture attraction part of tourism marketing activity done by relating institution include art show come from various ethnic in Semarang city. An event will be reached successful if it able creating new icon for its city while this promoting activity is hoped to be one of characteristic of Semarang city and raising Semarang city prestige if is compared with other city in Indonesia. The other promotion also includes exhibition and leaflet creating, brochure, guiding book, and tourism map who become information source for tourist to explore its destination and supporting facility in Semarang city. To introduce development and tourism marketing locally through society establishing into creating tourism concerning group known as Pokdarwis which is one of self help and spontaneous society group functioning as tourism activator through increasing tourism sectors include security, cleaning, arranged, fresh, friendly, beautiful and memorizing. The other is by implementing tourism promotion both of local and international through Denok (women embassy) Kenang (male embassy) Semarang city coordination as tourism ambassador.

Cultural and Tourism Institution of Semarang city take a role as tourism organization in region, ideally able to arrange Primary Tourism of Development Regional Planning abbreviated as (RIPPDA) hope can be become guidance of development and marketing planning or promotion strategy for local destination which is want more tourist visitation in this region. One of reference implementing program in Semarang city institution is Working Planning of Local Government Semarang city abbreviated as (RKPD). Based on it in 2015 from program planning recapitulation of tourism marketing development can be known that raising indicator of its program amount $7 \%$. While based on Strategy Planning of Cultural Development and National Tourism abbreviated as Renstra Disbudpar Semarang city in 2015, these activities include in this promotion development program/ tourism marketing aim to increase cultural industry and local tourism through marketing and promotion efforts, both of done in Indonesia and abroad. To increase Semarang city prestige in Indonesia and International aims to increase appreciation for local cultural industry, quality, serving and tourism information. But the successful achievement from this program implementing by relating institution in Semarang city refer to increasing tourist visitation amount. It is suitable with RKPD matrix of Semarang city in 2015 that is targeted able to reach amount $7 \%$. But based on data collecting, it can be known that tourist visitation in Semarang city hasn't given good news. The tourist visitation can be seen in the table below:

\section{Table 1}

Tourist Visitation Amount in Semarang City

\begin{tabular}{|c|c|c|}
\hline Year & $\begin{array}{c}\text { Local Tourist } \\
\text { (Increasing Number) }\end{array}$ & $\begin{array}{c}\text { Foreign Tourist } \\
\text { (Increasing Number) }\end{array}$ \\
\hline 2010 & $1,456,961$ & 8,144 \\
\hline 2011 & $1,624,270(10,3 \%)$ & $8,772(7,15 \%)$ \\
\hline 2012 & $1,887,673(13,9 \%)$ & $22,230(60,5 \%)$ \\
\hline 2013 & $2,892,227(34,7 \%)$ & $27,880(20,26 \%)$ \\
\hline 2014 & $2,073,046(-39,5 \%)$ & $14,450(-48,17 \%)$ \\
\hline
\end{tabular}

Source: Cultural and Tourism Institution Semarang city in 2015

Based on the data above, it can show that the tourist visitation amount hasn't increased significantly. From 2011 to 2012 show the local tourist escalating amount 3,6\% and for foreigner amount 53,35 \%, in 2012 and 2013 show the escalating amount 20,8 \% for local tourist and for foreigner decreasing amount 39,24\%, and the most worried is in 2013 and 
2014 period show the local tourist decreasing amount 4,8 \% and for foreigner amount 17,19 $\%$. The data collecting explanation above improve that tourism promotion implementation hasn't done optimally.

The promotion development program of tourism in Semarang city includes Mangkang zoo become one of aim to creating Semarang city prestige both of local and International, this activity will be aimed to increase both of local and national industry appreciation. To realizing this program so that it need society supporting to attain this program optimally. To productivity of marketing development program such as in tourism sector, it needs society role as tourism development subject while this program will be exact and efficient because they will decide this successful program. Ironical there are many societies in Semarang city haven't understood about Sapta Pesona as development supporting program of tourism surely will impact into pleasantness and tourist visitation in this region. The societies who support and expand tourism program surely they understand about Sapta Pesona. It is one of mindset of tourist or a community tourism that classified into security condition, cleaning, arranged, fresh, beautiful, friendly, and memorizing so that it will create sense of belonging against tourism in its territory.

One of example of the highest society awareness to make their city as a tourism destination is Bali. Balinese has understood about the important of Sapta Pesona in their territory, they are always taking care of clean and environment discipline especially for tourism destination. There are no illegal parking areas or garbage dispersing. But this condition is contrary with Semarang city. One of souvenir destination is around Pandanaran area, where there is many illegal parking areas and many garbage dispersing around this street that makes uncomfortable condition for tourist. It indicates about society awareness lowly around Pandanaran area to participate into discipline and environment cleaning as supporting development program of tourism in Semarang city.

The lack of supporting development program of tourism in Semarang city can be seen based on illustration condition in this city imaging as flooding area. Flooding is causing of human factors. The lack of society awareness both of resident construction or factory impacts into environment destruction such as flood. Surely it creates bad image for Semarang city. It is knower with its flood condition than its tourism potentiate. Ironically where the government program of tourism marketing is radical hasn't been supported by society awareness into caring for environment.

Tourism agency role in Semarang city as one of tourism stakeholder is also queried its role, where there is no special tourism package for Semarang city. But one of program is aimed to develop marketing into increasing quality, serving and tourism information, while they can be gotten from tourism agencies in Semarang. Generally, tourism agency in Semarang is more tending to promote other regional such as Bali, Yogyakarta, etc. Moreover it can be concluded that there is no tourist package for Semarang city. "The tourism package unavailable in Semarang city because this owner fell confuse in promoting tourism destination. The tourism destination is Semarang city is separated and the infrastructure is lack patronizing such as flood, traffic jam and the lack of supporting way to the rural destination around Semarang city. "Based on Mrs. Irani statement, the Regional House Representative ASITA Central Java into tourism agency owner locates in Grand Candi Hotel. There are many cultural and tourism potential in Semarang city attractively and available for tourism but it hasn't been managed seriously. The tourism agency owner and local government in Semarang city have their own idea and there is no synergy between festival organizer and tourism agency so that it hasn't been able invite visitor. As great as its festival celebrate, it has to been supported by 
government and all tourism stakeholder because it need cooperation for program successful. The lack of tourist visitation because there is no society supporting and tourism stakeholder so as local income escalation relate to tourism retribution possibility become one of indication into marketing development of tourism program which is implemented by Cultural and Tourism Institution in Semarang city hasn't done maximally.

The tourism activity is able to support its development which is effort to create multiplier effect both of directly or indirectly, based on the Regulation of Indonesia Republic number 10 in 2009 about the aiming of tourism development is to increase country currency exchange, expanding job opportunity and business activity, stimulating region development, and introducing nature so does its cultural, based on Pendit statement that the tourism take a role into giving contribution for economy, social, and cultural unity in Indonesia so does increasing degree and prestige especially for Semarang city. This research formulate about evaluation program through four dimensions such as: income (input) indicator, process, output, and outcome indicator. Because it aims to evaluate implementation program of tourism development in Mangkang zoo based on input, process, output and outcome dimensions.

\section{PREVIOUS RESEARCH}

a. Elyance Suci, 2012, so far this implementation program hasn't been done maximally. Where there is a problem about promotion program such as unavailability tourism promo for Semarang city, this agency in this city is more promoting other city tourism, there is many tours but they stand by their self, and actually there is many event which is able to be promoted but it hasn't been managed maximally.

b. Carl Crafton \& Anne Permalof, 2005, entitled Public Policy Process and Networking. The media take a role dominantly into decision process of politics, but this information content is more important.

c. Albert N. Kimbu and Michael Z. Ngoasong, 2013, Centralized Decentralization of Tourism Development: A Network Perspective, Annals of Tourism Research, the tourism development is not only giving benefit for stakeholder directly but also able to increase social economy for societies.

d. Chui, Hua Lie et al., 2012, Improving Tourism Policy Implementation: The Use of Hybrid MCDM Model, Tourism Management, the tourism policy is not only government liability, but also requiring cooperation both of private institution or societies. The structure that is developed based on implementation of tourism policy has to be influenced by many factors such as identification of tourism potentiate, mapping tourism industry, social economy condition of society and security aspect.

e. Fug, 2011, cooperation and policy analysis, advocacy condition will be able implementing seriously depending on similarity necessity and benefit.

\section{THEORETICAL FRAMEWORK}

Based on Scuhman (into Anderson and Jabar, 2014:1) explaining evaluation as an outcome decision process whose has been reached from many activities planned to support achieving goal. Generally this evaluation taking role as a process must have three functions such as: 1) determining advantage, 2) supporting program organizing, 3) repairing or recheck again. (Sudijono, 2005:8) states that something mean as evaluation program in this research is collecting information activity about proceeding program of government aiming to look for answer about outcome attaining, then it will be used to decide alternative way or accurate choice into decision making.

Based on Beni Setiawan (1999:20), principally of evaluation executing need to be created program which can be measured through as follows: 
a. Input indicator, is relate to supporting implementation program and deciding this successful program.

b. Process, illustrating how the activity results from an activity has proceeded.

c. Output indicator, illustrating how the activity results from an activity has proceeded.

d. Outcome indicator.

Evaluation is one of way to improve successful or failure into program implementation, therefore this evaluation meaning is often used to indicate cycle steps of management program including as follows:
a. Planning step evaluation ( EX-ANTE)
b. Implementing step evaluation ( ON-GOING )
c. Post implementing step evaluation (EX-POST)

Evaluation program focuses into budget is done by two steps such as assessment indicator of program performance based on output and outcome so does evaluation study program according to its impact. The first way is done through comparison of target performance indicator that is planned with realization, relevant and sufficient information has to prepare easily before a performance indicator program is assumed appropriate. The second way is done through data collecting and deep information refers to result, benefit, and effect of program that has been finished. The important thing is about information that is result and how do analyzing and reporting this information. This information has to be individual, objective, relevant and able to be relied. Based on the explanation above, it can be concluded that the evaluation program dimension used in this research consist of input, process, output, and outcome. To create this indicator, previously need to understand about basic concept of input, process, output, and outcome. The evaluation program of tourism promotion which is explained in this research is an evaluation activity of effort and activity pointed at organizing tourist attraction (both of nature destinations, maritime or cultural) so does in providing facility and infrastructure who support tourism activity and promoting tourist attraction.

The assessment of implementation and program outcome which is done in evaluation has to based on criterions obviously and objective. Because it aims to avoid disagreement and refusal of evaluation outcome whose has been done. There are many assessment criterions generally used into evaluation, while into evaluation program criterion of tourism marketing development aim to become assessment parameter of program evaluation has to be applied theory from Pollit and Bouckaert ( Keban.Y.T.2008:224) entitled: relevancy, efficiency, effective, liability and continuity.

\section{METHOD}

This research uses qualitative descriptive method because it presents phenomenon descriptively without considering quantity phenomenon appearing, but the deep information in its phenomenon. This research focuses into evaluation program of tourism promotion at Mangkang zoo tourist attraction in Semarang city. The technique of data collecting is done by Triangulasi, through three ways such as deep interviewing with many informants, questionnaire, and documentation.

\section{RESULTS AND DISCUSSION}

The first input is budget, in can be known that the budget availability into tourism promotion program isn't suitable with real necessity of program operational. This condition appears into allocating system of budget source from government who hasn't participative and effective, where the fund existence for this program has been concluded by budged team in its Local Government and Bappeda according to fund realization in previous year and RPJMD of 
Semarang city so that basic principle activity bases on budget. Whereas activity which is values effectively is activity which is funding system according to its activity (budget by activity). The second input is a human resource of promotion development of tourism program. Research dimension from its human resource is quality influencing (education background), quantity and utility or participation of relating human resource, and so does this human resource participation into successful program along with impact of existence position rotation. Bases on research, it can be known that human resource competency in Cultural and Tourism institution Semarang city totality hasn't expert about tourism, whereas the other human resource called as stakeholder often take a role into tourism promotion activity who come from Hotel association, Tourism Agency, Restaurant, Tourism Academy, Event Organizer, Denok (women embassy) Kenang (male embassy), etc. it shows that tourism stakeholder role is very important in this program.

So far government role is only as facilitator than a stakeholder exactly takes a role directly, whereas the tourism guide become a main thing so does human resource as a program motivator. Relating to position rotation as the third input, this program will be little influence if there is a leader or position changing who also cause into policy changing while causing instability and confusing between leader and its executor. The fourth input is facility and infrastructure. Generally they are able as supporting program by interlace cooperation with third party because limited own by relating institution. About the schedule and executing time activity as the fifth input can be known that tourism promotion is arranged together with celebration of historical days such as Semarang city anniversary so is province. While for information of executing time is separated through print media and electronic. For promotion structure so far can be known is more oriented to the concept or holistic promotion structure. It can be known from similarity promotion pattern of tourism which is done by Cultural and Tourism Institution in Semarang City with marketing concept or promotion stated by Kottler. According to Kotler and Keller (2009) concept or holistic promotion structure based on design development and implementation of marketing program, process and activity- activity because there is a extending character and dependence each other between many existence entity. Holistic marketing concept efforts to realize and understand about its range and complexity from marketing activity, which is able described into four elements such as: relationship marketing concept, integrated marketing concept, internal marketing concept, and performance marketing concept. They will be completing each other to able in realizing holistic marketing or marketing who comply with all relating necessity. The keywords of holistic marketing are existence effort to understand about "anything has a meaning as marketing". So that this marketing activity corps into strategic activity for factory, organization both of private or government. If it is compared with promotion structure that is done by Cultural and Tourism Institution has a similarity likes always interlace relation with tourism stakeholder so is local society aiming to increase their participation in all activities done.

According to the second dimension called as process, through activity aiming to increase technology information utilizing into tourism marketing. This activity includes supplying hot spot tool around Cultural and Tourism Institution office area. The modern tools have fulfilled 10 areas, it functions to make employee feeling easy in updating tourism data. This technology information will be known as E-Tourism. To support it, relating institution has made a website which can be accessed by all society. The second activity is implementation tourism promotion both of around Indonesia and abroad, includes: tourism exhibition gleam and Indonesian culture, participate into APEKSI event, art exhibition in Taman Mini Indonesia Indah known as TMII, and promoting characteristic culinary of Semarang city. Every activity has differential kind activity and differential goal. 
The third dimension called as output, promotion program so far hasn't implemented optimally who can be improved with many problems found in a field such as: (1) the decreasing of tourist visitation. It is because of uninteresting of tourist attraction existential, the lack or representative, and both of potential or promotion haven't been managed maximally. (2) There is not tourism package in Semarang city because the development of tourist attraction hasn't maximally and the distance around this destination is far relative. The other is inappropriate infrastructure such as flood, and cooperation with tourism stakeholder hasn't been related maximally into tourism package offering in Semarang city. (3) There isn't regulation which is able to be become guidance relating to strategy oriented to tourism stakeholder synergy. (4) Positioning rotation exist in Cultural and Tourism Institution also become one of obstacle within tourism promotion development in Semarang city, allowing for leader changing often cause into policy changing while baffling for officer in a field. (5) The lack of tourism promotion based on quantity aspect, allowing for investment class of creating tourist attraction in Semarang city is still low. So far the increasing investment rapidly is relating to MICE tourism.

The fourth dimension called as outcome, relating to economy rate of growth in Semarang city that is dominated by tertiary aspects such as hotel and restaurant. It shows that increasing facility of tourism supporting in Semarang city develop rapidly and giving contribution for economy growth in this city. Then it can be seen from contribution of tourism sectors also appear increasing about $12,82 \%$ in a year periodic. It impact to the increasing of society consume in Semarang city especially for take a trip. If it is based on the investment of tourism field in Semarang city, actually the government has given easy way for permitting, supporting infrastructure, and promotion for stakeholder candidate purposing to attract stakeholder in Semarang city. The rapid development for investment in tourism filed of Semarang city so far more oriented to the tourism service field such as starry hotel, restaurant, increasing other recreation area including golf court, sport centre, café, massage service, etc. based on this researches, it can be concluded that relation outcome hasn't done optimally, because there is still found many obstacles into investment and infrastructure.

This research uses assessment parameter of evaluation promotion of tourism development program refer to Pollit and Bouckaert (Keban,2008:224) theory (Keban, 2008:224) there are four term as follows: Relevance, means determining relating or relevancy between necessity (income) and goal (output) formulated. Where this researches consist of relevancy between income and program goal. The budget expended for tourism developing program has been sufficient because all of development program of tourism marketing start from income to the outcome able to determine and planning into Strategy Planning known as Renstra Disbudpar Semarang city. Efficiency, means comparison between input and output program. There is an efficiency relating to the budget because Semarang city government especially Disbudpar has been able looking for additional budget as supporting program activity. Efficiency, call as similarity class between goal and outcome so does its program. This research based on outcome determining who can't be done before it shows result hoped from an activity or program decided, because outcome determining includes comparison outcome which is reached with satisfying outcome. In fact this research still exist a publication program not optimally include the lack investment in tourism field relating to tourist attraction in Semarang city so that causing to the result and not optimally program. Utility and sustainability, means determining of utilizing and continuity between necessity and it impact resulted by this program. This research analyze about outcome program from tourism marketing development to society development in Semarang so that it can be used by local government especially for Disbudpar Semarang city to increase activity program and impact to the better economy condition. It improves attained continuity condition of tourism development program mainly into stimulating economy condition in Semarang city. 
The supporting factor and obstacle of program evaluation based on research finding that can be concluded as supporting and obstacle factors of tourism marketing development program as follows:

1. Supporting factors of tourism marketing development program

a. There is a supporting fund both of private and stakeholder.

b. The schedule of implementation program arranged correctly.

c. There is a support from society and private organization includes local government cooperation especially for Cultural and Tourism Institution together with national businessman into promotion act.

2. Obstacle factors of tourism marketing development program

a. The budget availability into tourism marketing development program hasn't suitable with real necessity of program operational.

b. Human resource quality from its institution and human resource competency outside its institution (tour guide) as activity executing are insufficient because of program unknown.

c. The lack of facility and supporting infrastructure of its program.

d. The tourist attraction isn't maximally separate around Semarang city so is the distance relatively far.

e. Infrastructure in Semarang city doesn't support.

\section{CONCLUSION AND SUGGESTION}

According to evaluation program results of tourism marketing of tourist attraction in Mangkang zoo from phenomenon in this research include: Input, Process, Output, and Outcome can be concluded that: input dimension availability fund become an obstacle into tourism promotion development or limited fund. This human resources aren't maximally where there is still a lack of supporting trainings program and education background of executor non competently. The other is tour guide competency or human resource outside government insufficiently. From output dimension there is still a problem so that the target isn't maximally, it because of uninteresting tourist attraction both of facility and infrastructure. The diversity and tourist attraction cleaning so does potential development and promotion aren't maximally. The deficiencies of tourism package in Semarang city because there is no cooperation between tourism stakeholders neither is regulation who can be become guidance into tourism marketing strategy. A government rotation is also become an obstacle into determining promotion strategy of tourism. Based on outcome dimension, generally is going better but there is a problem of the lack investment relates to tourist attraction. It is because of inappropriate infrastructures, traffic jam in everyday, flood, and hot temperature. Generally it can be assumed that research results of program evaluation of tourism are enough success, but there is an obstacle which has to be followed up and observed for future.

The recommendation delivered is obligation of budget enhancing into tourism promotion program and distribute separately in all tourist attraction availability, so does increasing competency for officer and tour guide professionally, arranging and maintaining tourist attraction need to be increased, escalating tourism networking, and involving society participation maximally.

\section{References}

Akdon, 2007, Strategic Management for Educational Manageent (Manajemen Strategik untuk Manajemen Pendidikan), Alfabeta, Bandung.

Anderson, James E, 2006, Public Policy Making: An Introduction, Boston: Houghton Muffin Company.

Arikunto, Suharsini dan Cepi Safruddin Abdul Jabar, 2004, Evaluation of Educational Program: Theoretical Practice Guidelines for Education Practitioner, Bumi Aksara, Jakarta. 
Blaine R Worten, James R Sanders and Jody. Fitzpatrick, 1997, Program Evaluation Alternative Approaches and Practical Guidelines, Longman Publishing, USA.

Daniel L. Sufflebeam, dan Anthony J. Shnkfield, 1986, Systematic Evaluation: A Self Instructional guide to Theory and Practice, Kluwer-nijhoff Publishing, Boston.

Fitzpatrick, Jody L, Sanders, James R, Worthen, Blaine R, 2004, Program Evaluation Alternative Approaches and Practical Guidelines, Pearson Education.

Hadi, Sutrisno, 1986, Research Method, Gadjah Mada University, Jogyakarta.

Indonesia, LANRI, 2004, Accountability Module System of Government Institution Performance, the Second Edition, Jakarta, LAN.

Jamrozy, Ute. 2006. Marketing of Tourism : a paradigm shift toward sustainability. International Journal of Culture, Tourism and Hospitality Research. Vol 1 No.2. 2007, pp. 117-130.

Keban, Yeremias T. (2008), The Sixth Dimension Strategy of Public Administration: Concept, Theory and Issue, Yayasan Obor Indonesia, Yogyakarta.

Moleong, Lexy, 2007, Qualitative Research Method, Remaja Rosdakarya, Bandung.

Nugroho, Riant, 2008, Public Policy: Policy Theory, Policy Analysis and Policy Process, PT Elex Media Komputindo, Jakarta.

Pasolong, Harbani, 2007, Public Administration Theory, Penerbit Alphabeta, Bandung.

Pendit, Nyoman, S, 1999, Tourism Science as a Main Conveyor, PT Raja Grafindo Persada, Jakarta

Singarimbun, Masri dan Sofyan Efendy, 1989, Methodology of Research Survey, LP3ES, Jakarta.

Smith, Kevin B. and Christopher W. Larimer, 2009, the Public Policy Theory Primer, Boulder: Westview Press.

Sudijono, Anas, 2005, Evaluation of Educational Conveyor, PT Raja Grafindo Persada, Jakarta.

Sunggono,Bambang.1994, Law and Public Policy. Jakarta: Sonar Grafika.

Subarsono, 2005, The Concept of Public Policy Analysis, Theory and Aplication, Penerbit Pustaka Pelajar, Jogyakarta.

Sugiyono, 2004, The Method of Administration Research, Penerbit Alfabetha Bandung.

Sutisna, Oteng, 2000, Basic Educational of Theoretical Administration for Professionalism, Angkasa, Bandung.

Thohir, Mudjahirin, 2013, Research Method of Social Cultural Based on Qualitative Approach, Fasindo Press, Semarang.

Van, Meter, D. And Van Horn, C. 1975. "The policy Implementation Process: A Conceptual Framework" into Administration and Society, 6, 445-448

Widodo,Joko.2009. Public Policy Analysis Concept and Analysis Application Process of Public Policy. Malang: Bayu Media.

Winarno, Budi. 2002. Public Policy: Theory and Process. Penerbit Media Pressindo. Jogyakarta.

Yusuf, Farida, T, 2000. Evaluation Program, PT Rineka Cipta, Jakarta.

\section{Other Sources:}

Regulation Law Number 39 in 2006 about Controlling Manner and Implementation Evaluation of Development Program.

Regulation Law Number 23 in 2014 about Local Government.

Cultural and Tourism Research of Indonesian Republic, 2010, Strategy Planning of Cultural Development and National Tourism 2010-2014, Jakarta. 